\author{
DE DE GRUYTER \\ OPEN
}

DOI 10.2478/aucft-2014-0015

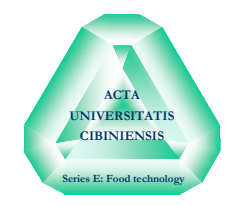

\title{
ENZYME-ASSISTED EXTRACTION OF POLYPHENOLS FROM ROSE (ROSA DAMASCENA MILL.) PETALS
}

\author{
Krasimira KALCHEVA-KARADZHOVA*, Vasil SHIKOV**, Kiril \\ MIHALEV***1 ${ }^{1}$, Georgi DOBREV**, Danka LUDNEVA*, Nikolai \\ PENOV** \\ *Food Research and Development Institute, 154 Vasil Aprilov Str., 4000 \\ Plovdiv, Bulgaria \\ **University of Food Technologies, 26 Maritza Blvd., 4000 Plovdiv, \\ Bulgaria
}

\begin{abstract}
The efficiency of enzyme-assisted extraction for the recovery of polyphenols from rose (Rosa damascena Mill.) petals was evaluated performing a simplex centroid experimental design for mixture with three components (pectinolytic, cellulolytic and hemicellulolytic preparation). The ternary enzyme combinations leaded to the highest contents of total polyphenols, reaching $43 \%$ higher average value as compared to the control (without enzymatic treatment) sample. Enzymatic treatments also enhanced (9-25\%) the extractability of total anthocyanins. The results obtained demonstrate that enzyme-assisted extraction improves the recovery of polyphenolic antioxidants from rose petals, especially using ternary enzyme combinations, comprising pectinolytic, cellulolytic and hemicellulolytic preparation.
\end{abstract}

Keywords: polyphenols, enzyme-assisted extraction, Rosa damascena.

\section{INTRODUCTION}

Rosa damascena Mill., which belongs to the family Rosaceae and genus Rosa, is an important essential oil crop, with Bulgaria and Turkey being the main rose petal processing countries in the world (Ginova et al., 2013). Plants from genus Rosa have been used in phytopharmaceutical, essential oil and food industries for many years (Fenglin et al., 2004). Many studies (Cho et al., 2003; Ng et al., 2004; VanderJagt et al., 2002; Vinokur et al., 2006)

\footnotetext{
${ }^{1}$ Corresponding author. Mailing address: Associate professor PhD Kiril Mihalev, University of Food Technologies, 26 Maritza blvd., 4000, Plovdiv, Bulgaria. E-mail: kmihalev@yahoo.com
}

Vol. 18 (2014), no. 2 
associated the antioxidant activity of aqueous extracts from rose petals, primarily, with the presence of phenolic compounds. In addition to the antioxidant capacity, rose petal extracts have been reported to possess antiinflammatory and analgesic (Choi and Hwang, 2003), antibacterial (Anesini and Perez, 1993; Perez and Anesini, 1994), antiviral (Mahmood et al., 1996) and antifungal (Dixit et al., 1976; Anesini and Perez, 1993) effects.

Enzyme-assisted extraction is gaining increasing attention as an advanced process to enhance the recovery of bioactive compounds from plant matrices. Cellulases, hemicelullases, and pectinases, as well as other enzymes, can be used to catalyze the hydrolysis of the cell wall polysaccharides, thus, enabling a better release and a more efficient extraction of phenolic compounds (Pinelo et al., 2008).

Therefore, the present study evaluated the efficiency of enzyme-assisted extraction for the recovery of polyphenols from Rosa damascena petals. In order to determine the optimal enzyme composition, a simplex centroid experimental design for mixture with three components (pectinolytic, cellulolytic and hemicellulolytic preparation) was performed.

\section{MATERIALS AND METHODS}

Chemicals: For analytical purposes the following reagents were used: DPPH [2,2-diphenyl-1-picrylhydrazyl] and Trolox [(+/-)-6-hydroxy-2,5,7,8tetramethyl-chroman-2-carboxylic acid] (Sigma-Aldrich, Steinheim, Germany); TPTZ [2,4,6-tripyridyl-s-triazine] and gallic acid monohydrate (Fluka, Buchs, Switzerland); Folin-Ciocalteau's reagent (Merck, Darmstadt, Germany). All the other reagents and solvents used were of analytical grade.

Enzyme preparations: The following commercial enzyme preparations were used: pectinolytic preparation Pectinex Ultra Color (Novozymes A/S, Bagsvaerd, Denmark); cellulolytic preparation Rohament CL (AB Enzymes GmbH, Darmstadt, Germany); hemicellulolytic preparation Xylanase AN (Biovet JSC, Peshtera, Bulgaria).

Plant material: Rose (Rosa damascena Mill.) petals, harvest year 2013, were supplied by Ecomaat Ltd. (Mirkovo, Bulgaria). The petals were dried in a thin layer at room temperature $\left(25-27^{\circ} \mathrm{C}\right)$ for one week before final hot air drying $\left(50^{\circ} \mathrm{C}, 1 \mathrm{~h}\right)$. Dried rose petals were stored in a desiccator in dark until used.

Enzyme-assisted extraction: Finely ground (particle size $<0.63 \mathrm{~mm}$ ) rose petals were mixed with water (12:1, v/w), acidified ( $\mathrm{pH} 3.0)$ with $1 \mathrm{M} \mathrm{HCl}$, and left overnight for rehydration at $10 \mathrm{C}$. After $\mathrm{pH}$ adjustment $(\mathrm{pH} 3.0)$, the suspension $(100.0 \mathrm{~g})$ was placed in a $50{ }^{\circ} \mathrm{C}$ water bath for $20 \mathrm{~min}$ before 10 $\mathrm{mL}$ of an acidified water solution $(1.2 \%, \mathrm{v} / \mathrm{v})$ of enzyme preparation (single or mix) were added. After incubation for $2 \mathrm{~h}$ at $50{ }^{\circ} \mathrm{C}$, the sample was placed

Vol. 18 (2014), no. 2 
in a boiling water bath for 10 min to inactivate enzymes, then immediately cooled in an ice bath and centrifuged $\left(4200 \mathrm{~g} \times 15 \mathrm{~min}, 25{ }^{\circ} \mathrm{C}\right)$. The supernatant obtained was filtered through a paper filter.

Enzyme preparations were applied according to the following simplex centroid experimental design (Figure 1): 1 - 100\% Pectinex Ultra Color (X1); 2 - 100\% Rohament CL (X2); 3 - 100\% Xylanase AN (X3); mix 1 - X1:X2 = $1: 1 ; \operatorname{mix} 2-\mathrm{X} 1: \mathrm{X} 3=1: 1 ; \operatorname{mix} 3-\mathrm{X} 2: \mathrm{X} 3=1: 1 ; \operatorname{mix} 4,5,6-\mathrm{X} 1: \mathrm{X} 2: \mathrm{X} 3=$ $1: 1: 1$.

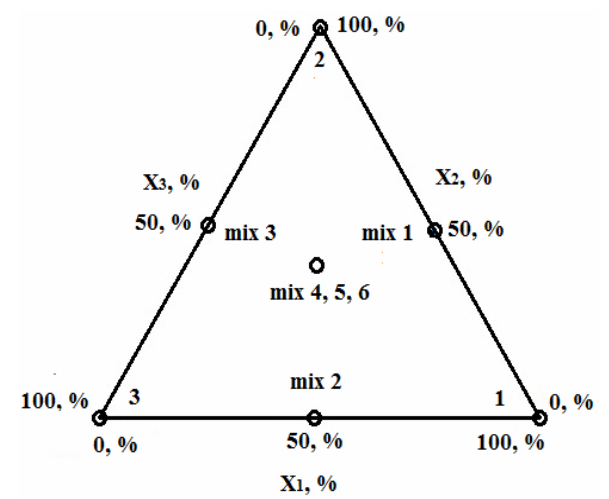

Figure 1. Ternary diagram for the simplex centroid experimental design: X1 Pectinex Ultra Color; X2 - Rohament CL; X3 - Xylanase AN.

Sample preparation: An aliquot (5 g) of filtered extract was transferred into $50 \mathrm{~mL}$ volumetric flask using $40 \mathrm{ml}$ of acidified $(0.1 \% \mathrm{HCl})$ methanol. After extraction for $24 \mathrm{~h}$ at $10{ }^{\circ} \mathrm{C}$, the flask was filled up to the mark with acidified methanol and filtered through a paper filter. Extraction was performed in triplicate.

Analytical methods: All measurements were performed with a Helios Omega UV-Vis spectrophotometer equipped with VISIONlite software (all from Thermo Fisher Scientific Inc., Waltham, MA, USA) using $1 \mathrm{~cm}$ path length cuvettes.

The contents of total polyphenols (TPP) and total monomeric anthocyanins (TMA) were determined by the method of Singleton and Rossi (1965) and the pH-differential method (Giusti and Wrolstad 2001), respectively, modified as described by Dinkova et al. (2012).

The total antioxidant capacity was determined by the DPPH (free radical scavenging activity) and FRAP (ferric reducing antioxidant power) assay, following the methods of Brand-Williams et al. (1995) and Benzie and Strain (1996), respectively, with some modifications (Dinkova et al., 2012).

Determination of enzyme activities: Endoglucanase, xylanase, $\beta$-xylosidase, $\beta$-glucosidase, polygalacturonase and protease activities of the enzyme preparations were determined using carboxymethyl cellulose (Dobrev et al., 2012), oat xylan (Dobrev et al., 2007), p-nitrophenyl- $\beta$-D-xylopyranoside

Acta Universitatis Cibiniensis Series E: FOOD TECHNOLOGY

Vol. 18 (2014), no. 2 
(Ponpium et al., 2000), p-nitrophenyl- $\beta$-D-glucopyranoside (Ponpium et al., 2000), pectin (Miller, 1959) and casein (Kaverzneva, 1971) as substrate, respectively.

Statistical analysis: The results reported in the present study are the mean values of at least three analytical determinations and the coefficients of variation, expressed as the percentage ratios between the standard deviations and the mean values, were found to be $<5 \%$ in all cases. The means were compared using one-way ANOVA, performed with Microsoft Excel, and Tukey's test at a $95 \%$ confidence level.

\section{RESULTS AND DISCUSSIONS}

Significant increases in the extract yields, contents of total polyphenols and anthocyanins and antioxidant capacity values were observed in response to the enzymatic treatments (Table 1).

As seen in Figure $2 b$, the ternary enzyme combinations leaded to the highest contents of total polyphenols, reaching $43 \%$ higher average value for the mix 4-6 extracts (Table 1) as compared to the control (without enzymatic treatment) sample. Consistent with Miron et al. (2013), these results suggest extensive cell wall degradation due to the combined action of the pectinolytic, cellulolytic and hemicellulolytic preparation.

Table 1.Treatment variants and results ${ }^{a}$ for the simplex centroid design

\begin{tabular}{|c|c|c|c|c|c|}
\hline $\begin{array}{c}\text { Treatment } \\
\text { variant }\end{array}$ & $\begin{array}{c}\text { Yield } \\
(\%)\end{array}$ & $\begin{array}{c}\mathrm{TPP}^{b} \\
(\mathrm{mg} \text { GAE} / \\
100 \mathrm{~g})\end{array}$ & $\begin{array}{c}\mathrm{DPPH}^{c} \\
(\mu \mathrm{mol} \mathrm{TE} / \\
100 \mathrm{~g})\end{array}$ & $\begin{array}{c}\mathrm{FRAP}^{c} \\
(\mu \mathrm{mol} \mathrm{TE} / \\
100 \mathrm{~g})\end{array}$ & $\begin{array}{c}\mathrm{TMA}^{d} \\
(\mathrm{mg} \text { CGE} / \\
100 \mathrm{~g})\end{array}$ \\
\hline $\begin{array}{c}\text { Control } \\
(\text { no enzyme })\end{array}$ & $34 \pm 1 \mathrm{a}$ & $308 \pm 4 \mathrm{a}$ & $2163 \pm 45 \mathrm{a}$ & $1114 \pm 15 \mathrm{a}$ & $12.6 \pm 0.1 \mathrm{a}$ \\
\hline 1 & $46 \pm 1 \mathrm{~b}$ & $389 \pm 5 \mathrm{~b}$ & $2733 \pm 56 \mathrm{~b}$ & $1864 \pm 25 \mathrm{~b}$ & $15.1 \pm 0.1 \mathrm{~b}$ \\
\hline 2 & $41 \pm 1 \mathrm{c}$ & $325 \pm 4 \mathrm{c}$ & $1714 \pm 35 \mathrm{c}$ & $1445 \pm 19 \mathrm{c}$ & $13.8 \pm 0.1 \mathrm{c}$ \\
\hline 3 & $50 \pm 1 \mathrm{~d}$ & $359 \pm 4 \mathrm{~d}$ & $2786 \pm 57 \mathrm{bd}$ & $1745 \pm 23 \mathrm{bd}$ & $14.4 \pm 0.1 \mathrm{~d}$ \\
\hline Mix 1 & $50 \pm 1 \mathrm{~d}$ & $358 \pm 4 \mathrm{~d}$ & $2692 \pm 55 \mathrm{bd}$ & $1835 \pm 24 \mathrm{bd}$ & $15.6 \pm 0.1 \mathrm{e}$ \\
\hline Mix 2 & $50 \pm 1 \mathrm{~d}$ & $352 \pm 4 \mathrm{~d}$ & $2537 \pm 52 \mathrm{e}$ & $1855 \pm 25 \mathrm{e}$ & $14.6 \pm 0.1 \mathrm{df}$ \\
\hline Mix 3 & $50 \pm 1 \mathrm{~d}$ & $368 \pm 4 \mathrm{de}$ & $2405 \pm 50 \mathrm{e}$ & $1774 \pm 24 \mathrm{f}$ & $13.7 \pm 0.1 \mathrm{cg}$ \\
\hline Mix 4,5,6 & $51 \pm 1 \mathrm{~d}$ & $441 \pm 5 \mathrm{f}$ & $2767 \pm 57 \mathrm{bdf}$ & $1784 \pm 24 \mathrm{bdg}$ & $15.7 \pm 0.1 \mathrm{eh}$ \\
\hline
\end{tabular}

${ }^{a}$ Means \pm standard deviations $(\mathrm{n}=3)$. Different letters within a column indicate significant differences (Tukey's test, $\mathrm{P}<0.05$ ).

${ }^{b}$ Results are expressed as mg gallic acid equivalents (GAE) per $100 \mathrm{~g}$.

${ }^{c}$ Results are expressed as $\mu$ mol Trolox equivalents (TE) per $100 \mathrm{~g}$.

${ }^{d}$ Results are expressed as mg cyanidin 3-glucoside equivalents (CGE) per $100 \mathrm{~g}$.

Enzymatic treatments enhanced (9-25\%) the extractability of total anthocyanins (Table 1, Figure 2e). However, increasing the proportions of the

Acta Universitatis Cibiniensis Series E: FOOD TECHNOLOGY

Vol. 18 (2014), no. 2 
cellulolytic (X2) and/or hemicellulolytic (X3) preparation, the anthocyanin recovery decreased, which may be attributed to the secondary activity profiles (Table 2) of the enzyme preparations.
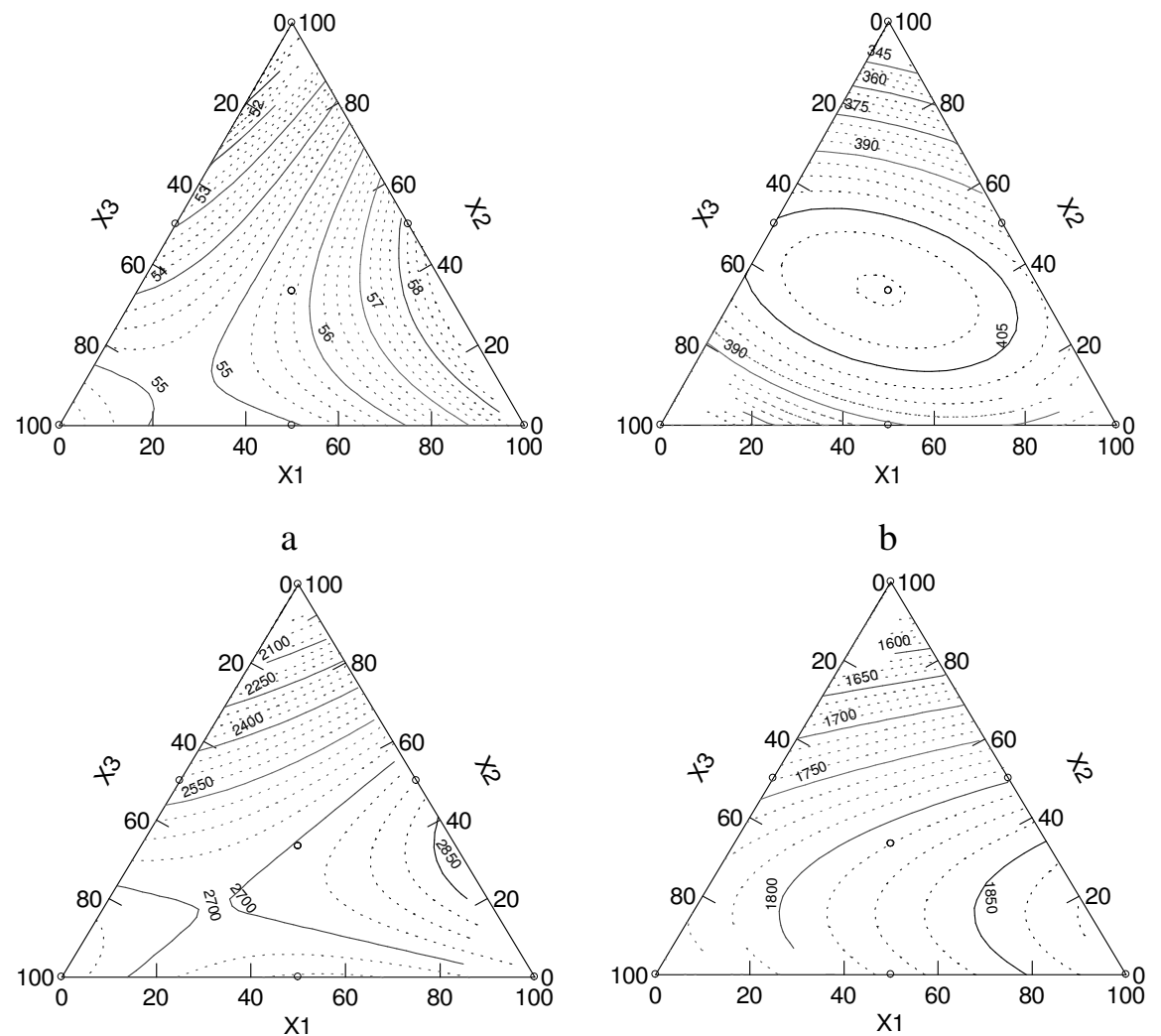

$\mathrm{c}$

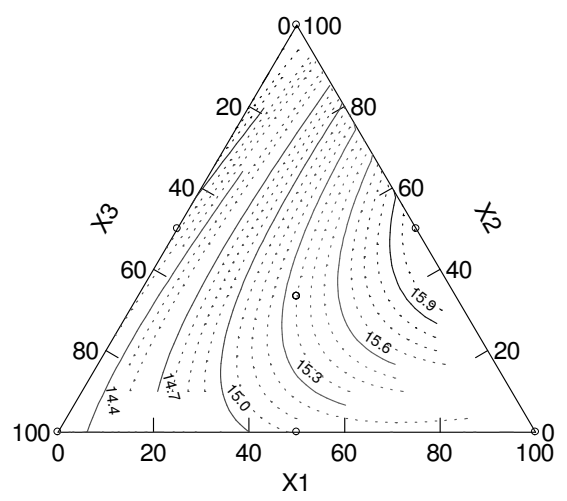

e

Figure 2. Simplex contour plots for the extract yield (a), TPP (b), DPPH (c), FRAP (d) and TMA (e). Enzymatic treatment variants as in Table 1.

Vol. 18 (2014), no. 2 
The presence of $\beta$-glycosidases causes deglycosylation of the anthocyanidin glycosides, which in turn results in unstable anthocyanin aglycons and a subsequent decrease in anthocyanin levels.

Table 2.Activity profiles of the enzyme preparations

\begin{tabular}{lccc}
\hline \multirow{2}{*}{ Enzyme activity } & \multicolumn{3}{c}{ Enzyme preparation } \\
\cline { 2 - 4 } & $\mathrm{X} 1^{a}$ & $\mathrm{X} 2^{a}$ & $\mathrm{X} 3^{b}$ \\
\hline Xylanase & 1790.4 & 2086.1 & 6286.8 \\
Polygalacturonase & 706.5 & 290.4 & 411.7 \\
$\beta$-Xylosidase & 7.2 & 49.3 & 20.0 \\
$\beta$-Glucosidase & 9.6 & 80.9 & - \\
Protease & 12.7 & - & 36.4 \\
Endoglucanase & 437.5 & 2333.1 & 619.7 \\
\hline
\end{tabular}

${ }^{a}$ Results are expressed in U/mL; ${ }^{b}$ Results are expressed in U/g.

The two assays used represent different mechanisms of evaluating antioxidant capacity. While the DPPH assay measures the ability of plant extracts to scavenge free radicals, the FRAP assay quantifies the total concentration of redox-active compounds (Magalhães et al., 2008). In general, the changes of the total antioxidant capacity (Table 1, Figure $2 \mathrm{c}$ and Figure $2 \mathrm{~d}$ ) correspond to the results obtained for the total polyphenols.

\section{CONCLUSIONS}

The results obtained demonstrate that enzyme-assisted extraction enhances the recovery of polyphenolic antioxidants from rose petals, especially using ternary enzyme combinations, comprising pectinolytic, cellulolytic and hemicellulolytic preparation. This new process may offer an environmentally-friendly alternative to the conventional organic solvent extraction. However, further studies optimizing enzymatic treatment conditions, e.g. enzyme combination dosage and time-temperature regime, are required.

\section{ACKNOWLEDGEMENTS}

We are grateful to Ecomaat Ltd. (Mirkovo, Bulgaria) for providing the rose petals.

\section{REFERENCES}

1. Anesini C. \& Perez C. (1993). Screening of plants used in Argentine folk medicine for antimicrobial activity. J. Ethnopharmacol., 39, 119-128. DOI: 10.1016/0378-8741(93)90027-3.

2. Benzie I.F.F. \& Strain J.J. (1996). The ferric reducing ability of plasma (FRAP) as a measure of "antioxidant power": The FRAP assay. Analytical Biochemistry, 239(1), 70-76. DOI: 10.1006/abio.1996.0292.

Acta Universitatis Cibiniensis Series E: FOOD TECHNOLOGY

Vol. 18 (2014), no. 2 
3. Brand-Williams W., Cuvelier M.E. \& Berset C. (1995). Use of a free radical method to evaluate antioxidant activity. $L W T-$ Food Science and Technology, 28(1), 25-30. DOI: 10.1016/S0023-6438(95)80008-5.

4. Cho E.J., Yokozawa T., Rhyu D.Y., Kim S.C., Shibahara N. \& Park J.C. (2003). Study on the inhibitory effects of Korean medicinal plants and their main compounds on the 1,1-diphenyl-2-picrylhydrazyl radical, Phytomedicine, 10(6-7), 544-551. DOI: 10.1078/094471103322331520.

5. Choi E.M. \& Hwang J.K. (2003). Investigations of anti-inflammatory and antinociceptiveactivities of Piper cubeba, Physalis angulata and Rosa hybrida. J. Ethnopharmacol., 89(1), 171-175. DOI: 10.1016/S03788741(03)00280-0.

6. Dinkova R., Shikov, V., Mihalev K., Velchev Z., Dinkov H. \& Mollov P. (2012). Changes in the total anthocyanins and polyphenols during processing of wild berries into freshly pressed juices. Journal of EcoAgriTourism, 8(1), 254-259.

7. Dixit N., Tripathi C. \& Upadhyay R. (1976). The antifungal substance of rose flowers (Rosa indica). Econ. Bot., 30, 371-374. DOI:10.1007/BF02904658.

8. Dobrev G. \& Zhekova B. (2012). Biosynthesis, purification and characterization of endodlucanase from xylanase, produsing strain Aspergilus niger B03. Brazilian Journal of Microbiology, 43(1), 70-77. DOI: $10.1590 / \mathrm{S} 1517-83822012000100008$.

9. Dobrev G., Pishtiyski I., Stanchev V. \& Mircheva R. (2007), Optimization of nutrient medium containing agricultural wastes for xylanase production by Aspergillus niger B03 using optimal composite design. Bioresource Technology, 98(14), 2671-2678. DOI:10.1016/j.biortech.2006.09.022.

10. Fenglin H., Ruili L., Bao H. \& Liang M. (2004). Free radical scavenging activity of extracts prepared from fresh leaves of selected Chinese medicinal plants. Fitoterapia, 75(1), 14-23. DOI: 10.1016/j.fitote.2003.07.003.

11. Ginova A., Mihalev K. \& Kondakova V. (2013). Antioxidant capacity of petals and leaves from different rose (Rosa damascena Mill.) plantations in Bulgaria. International Journal of Pure Applied Bioscience, 1, 38-43.

12. Giusti M.M. \& Wrolstad R.E. (2001). Characterization and measurement of anthocyanins by UV-visible spectroscopy. In R.E. Wrolstad (Ed.), Current Protocols in Food Analytical Chemistry (pp. F1.2.1-F1.2.13), New York: Wiley.

13. Kaverzneva E.D. (1971). Assay for determination of proteolytic activity of complex enzymes and proteinases. Prikladnaja biochimia $i$ Mikrobiologia, 7, 225-228 (in Rusian).

Vol. 18 (2014), no. 2 
14. Magalhães L.M., Segundo M.A., Reis S. \& Lima J.L.F.C. (2008). Methodological aspects about in vitro evaluation of antioxidant properties. Analytica Chimica Acta, 613(1), 1-19. DOI: 10.1016/j.aca.2008.02.047

15. Mahmood N., Piacente S., Pizza C., Burke A., Khan A.I. \& Hay A.J. (1996). The anti-HIVactivity and mechanisms of action of pure compounds isolated from Rosa damascena. Biochem. Biophys. Res. Comm., 229(1), 73-79. DOI: 10.1006/bbrc.1996.1759.

16. Miller G.L. (1959). Use of dinitrosalicyclic acid reagent for determination of reducing sugar. J. Anal. Chem., 31(3), 426-428. DOI: $10.1021 / \mathrm{ac} 60147 \mathrm{a} 030$

17. Miron T.L., Herrero M. \& Ibáñez E. (2013). Enrichment of antioxidant compounds from lemon balm (Melissa officinalis) by pressurized liquid extraction and enzyme-assisted extraction. Journal of Chromatography A, 1288(3), 1-9. DOI: 10.1016/j.chroma.2013.02.075.

18. Ng T.B., He J.S., Niu S.M., Zhao L., Pi Z.F., Shao W.\& Liu F. (2004). A gallic acid derivative and polysaccharides with antioxidative activity from rose (Rosa rugosa) flowers. J. Pharm. Pharmacol., 56, 537-545. DOI: $10.1211 / 0022357022944$.

19. Perez C. \& Anesini C. (1994). In vitro antibacterial activity of Argentine folk medicinal plants against Salmonella typhi. J. Ethnopharmacol., 44(1), 41-46. DOI: 10.1016/0378-8741(94)90097-3.

20. Pinelo-Jiménez M. \& Meyer A.S. (2008). Enzyme-assisted extraction of antioxidants: Release of phenols from vegetal matrixes. Electronic Journal of Environmental, Agricultural and Food Chemistry, 7(8), 3217-3220.

21. Ponpium P., Ratanakhanokchai K. \& Kyu K. (2000). Isolation and properties of a cellulosome-type multienzyme complex of the thermophilic Bacteroides sp. strain P-1. Enzyme Microbial. Technol., 26(5-6), 459-465. DOI: 10.1016/S0141-0229(99)00195-7.

22. Singleton V.L. \& Rossi J.A. Jr. (1965). Colorimetry of total phenolics with phosphomolybdic-phosphotungstic acid reagents. American Journal of Enology and Viticulture, 16, 144-158.

23. VanderJagt T.J., Ghattas R., VanderJagt D.J., Crossey M. \& Glew R.H. (2002). Comparison of the total antioxidant content of 30 widely used medicinal plants of New Mexico. Life Sci., 70(9), 1035-1040 DOI: 10.1016/S0024-3205(01)01481-3.

24. Vinokur Y., Rodov V., Reznick N., Goldman G., Horev B., Umiel N. \& Friedman H. (2006). Rose petal tea as an antioxidant-rich beverage: cultivar effects, J. Food Sci., 71, S42-S47. DOI: 10.1111/j.13652621.2006.tb12404.x.

Vol. 18 (2014), no. 2 